\title{
The impact of sociodemographic conditions on quality of life among adolescents in a Brazilian birth cohort: a longitudinal study
}

\author{
Helen Gonçalves, ${ }^{1}$ David A. González, ${ }^{1}$ Cora Luiza Araújo, ${ }^{1}$ \\ Luciana Anselmi, ${ }^{1}$ and Ana M. B. Menezes ${ }^{1}$
}

Suggested citation Gonçalves H, González DA, Araújo CL, Anselmi L, Menezes AMB. The impact of sociodemographic conditions on quality of life among adolescents in a Brazilian birth cohort: a longitudinal study. Rev Panam Salud Publica. 2010;28(2):71-9.

ABSTRACT Objective. To examine associations between certain aspects of self-reported Quality of Life (QoL) in early adolescence, and gender, skin color, maternal education at birth, and changes in socioeconomic position (SEP) occurring from 0-11 years of age.

Methods. A longitudinal study of a birth cohort composed of 5249 individuals born in 1993 in Pelotas, Brazil, who were followed periodically from birth to age 11. Socioeconomic variables were collected at birth in 1993, and again, in 2004. The following eight variables were analyzed: relationship with mother, relationship with father, family conflicts, physical punishment by parents, family relationship problems, discrimination, academic failure, and fear of neighborhood of residence. Adjustments were made using a hierarchical model.

Results. Skin color was related to all the variables (more so for nonwhites than for whites), except in family conflicts. Physical punishment and academic failure were more frequent in males. Discrimination and fear of neighborhood were more prevalent in females. Maternal education at birth was inversely associated, especially with failing/repeating a grade in school (19.5 times more frequent in the lower maternal education group than in the highest). A similar pattern was found with the SEP change: worse QoL in the group that was always poor (at birth and at 11 years of age) than in the group that was never poor. Fear of neighborhood was not related to maternal education or SEP change.

Conclusions. Gender, skin color, maternal education, and SEP change were related to various measured aspects of QoL. These results should be considered in policymaking that seeks to minimize inequities at birth, across the life-course, and for future generations.

Key words Quality of life; cohort studies; longitudinal studies; adolescent; socioeconomic factors; poverty; Brazil.

The terms "quality of life" (QoL) and "well-being" are often used to measure different realms of an individual's satisfaction with existence and experience in an attempt to understand how social, individual, and emotional factors influence

Post-graduate Program in Epidemiology, Federal University of Pelotas, Brazil. Send correspondence to Helen Gonçalves, hdgs.epi@gmail.com behavior and lifestyle. The World Health Organization's QoL assessment (WHOQoL) defines QoL as "the individuals' perception of their position in life in the context of the culture in which they live and in relation to their goals, expectations, standards, and concerns" (1).

Nevertheless, QoL has many differing definitions (2-4), reflecting the theoretical divergences in this area. As a result, various standardized and validated instruments have been proposed for evaluating QoL, most of which include a wide range of variables for measuring the social, emotional, health-related, and other dimensions of QoL (5). Most of these instruments provide a rating score for classifying the subject as having or not having QoL. Regardless, the different dimensions of QoL can be evaluated indi- 
vidually for a better understanding of the causal pathways and relationships with various independent variables (6).

Most studies that evaluate QoL are cross-sectional because they are based on the assumption that short-term experiences are the major determinants $(7,8)$. Nevertheless, certain early life events can also have long-term effects on various aspects of QoL. Over the last 20 years, as the hypothesis of the early origins of adult diseases (9) has emerged, a number of longitudinal studies have attempted to determine to what extent adverse events that occur during gestation and/or in the first years of life may predispose individuals to various diseases $(10,11)$. However, studies on how such determinant events influence QoL are scarce and limited to high-income countries (HIC) (12-14). Recognizing the impact of these early adverse events on health conditions-including chronic diseases, biological variables, and different aspects of human capital (height, school achievement, economic productivity, and birthweight of offspring)-special attention has been given to the effects of life-course socioeconomic trajectories and racial and gender inequities on these outcomes (15). In addition, some of these effects can even be transmitted to offspring (intergenerational effects), reinforcing inequities in the next generation $(16,17)$. Nevertheless, even in HIC there is a lack of information about the impact of early poverty, skin color, and gender on QoL in adolescence and adulthood.

Considering that QoL is a multidimensional construct that includes physical, emotional, mental, social, and behavioral components (17), the present study investigated early sociodemographic variables (socioeconomic position, skin color, and gender) as risk factors associated with family and social outcomes in adolescence. The main hypotheses to be tested was that these objective and subjective aspects-reflecting the QoL social domainare especially influential among males, black/brown individuals, offspring of mothers who had little education at the time of birth, and in those who are and always have been poor (at birth and in adolescence). To achieve these objectives, the present study evaluated the 1993 Pelotas Birth Cohort Study (Brazil), which used one of the few cohorts in low- and middle-income countries, and included data on sociodemographic, nutritional, and health-related variables collected di- rectly through several follow-ups from shortly after birth to 11 years of age (18).

\section{MATERIALS AND METHODS}

Pelotas is a city in southern part of Brazil with a population of approximately 340 000. In 2002, the city had a per-capita Gross Domestic Product of US\$ 1958 (national mean, US\$ 2 604). All children born in 1993 whose mothers lived in the municipality's urban area at the time of birth were eligible for participation in the study $(n=5249)$, covering approximately $99 \%$ of births in the city that year. This is one of the largest and longest-standing birth cohorts in middle-income countries (19). With the exception of 16 mothers that either could not be interviewed or refused to participate in the study, all others were interviewed and had their children examined shortly after birth. Children were subsequently followed-up on numerous occasions from infancy to 11 years of age (20). One of the last follow-up studies was carried out from July 2004-March 2005 and included 4482 adolescents who were known to be living and could be located. After 30 refusals $(0.7 \%)$, a total of 4452 adolescents were interviewed. Considering those who were known to have died $(n=141)$, the follow-up rate was $87.5 \%$. Information on socioeconomic, demographic, and health variables was collected at each visit. Details regarding follow-up visits are described in another study (20).

During the 2004-2005 follow-up, three questionnaires were administered: two to the adolescents (one face-to-face and one confidential) and one to the parent/ guardian. The face-to-face instrument investigated academic achievement, behavioral variables, nutritional status, health conditions, and discrimination. The confidential questionnaire investigated alcohol and drug use, family relationships, and sexual behavior. A guardian (preferably the subject's mother) provided information on socioeconomic, demographic, and maternal health conditions.

One of the aims in this follow-up was to evaluate family and social relationships in adolescence through selfreporting. This information was not collected according to any specific, previously available QoL questionnaire. Self-reported questions were considered as a proxy for evaluation of the social domain of QoL. The topics included were: (a) family relationships (perceived relationship with mother and father, family conflicts, and physical punishment); (b) educational achievement; (c) perception of neighborhood safety; and, (d) perception of discrimination. Given that QoL is based on individual perception, some questions were selected from among other variables collected at 11 years of age because they were considered good indicators due to some subjectivity (i.e., dissatisfaction with frequent physical punishment).

The family aspects of QoL were evaluated using four variables: (a) relationship with mother, collected as ordinal variables (excellent, very good, good, regular, and very poor relationshipsubjects that defined their relationship as regular or very bad were classified as having a "poor relationship with their mother"); (b) relationship with father, collected and categorized as above; (c) frequent family conflicts compared with other families, collected as a dichoto mous variable; and, (d) physical punishment by parents in the last 6 months, collected as a continuous variable. Frequent punishment was defined as occurring six or more times. In addition, an outcome variable was generated that combined responses for all of the above variables to obtain a comprehensive assessment of the family aspects of QoL. Different cutoff points were tested and individuals with two or more adversely-affected family aspects were classified as having family relationship problems since these were more closely related to the independent variables.

The social aspects of QoL were evaluated using three variables: (a) fear of the neighborhood of residence, collected as a dichotomous variable; (b) suffering discrimination for any reason (race, religion, socioeconomic position, physical disability, or other), analyzed as a dichotomous variable; and, (c) academic failure, collected as a numeric variable and analyzed as a dichotomous variable (failure $>1$ time in life).

The independent variables were collected at different follow-up visits. The subject's gender was collected in 1993. Self-reported skin color was collected in 2004-2005 and categorized as white, black, mixed, yellow, and indigenous according to the classification of the Brazilian Institute of Geography and Statistics (21). All the results for the last four groups were very similar, and for this 
reason skin color was classified as white or nonwhite.

The main socioeconomic position (SEP) indicator at birth used in the analyses was maternal education. This exposure has been more strongly related to different components of an offspring's health than other socioeconomic variables, especially in the first years of life (22). Maternal education level was collected in 1993 as a numeric variable and analyzed as a categorical variable $(0-4$ years of education; 5-8 years; $9-11$ years; and $\geq 12$ years).

To evaluate socioeconomic trajectories, two variables were considered: family income at birth (based on income of all family members) and family possession of consumer goods. To ensure comparability between both periods, the variables were divided into quintiles. SEP change between birth and 11 years of age was classified as: (a) always poor (lowest quintile at birth and at 11 years); (b) never poor (quintiles $2-5$ at birth and 11 years); (c) poor-non-poor (lowest quintile at birth and quintiles $2-5$ at 11 years); and (d) non-poor-poor (quintiles 2-5 at birth and lowest quintile at 11 years).

Multivariable analysis was carried out by Poisson regression based on a conceptual model taking into account a proposed hierarchy of causal relationships. The most distal level included skin color, sex, and maternal education, which may influence SEP change. The last variable was included in a second level. Prevalences were estimated for all variables. For crude analysis, the Chi-square test was used. For adjusted analyses, the Poisson regression with robust variance was used to estimate prevalence ratios (PR) and their respective Confidence Intervals $(95 \% \mathrm{CI})$. Tests for heterogeneity or for trend were performed according to the nature of the exposures. Variables whose significance level after adjustment for variables in the same or higher levels was $\leq 0.2$ were kept in the model. Stata 9.0 software (StataCorp LP, College Station, Texas, United States of America) was used for data analysis.

The approval of the Federal University of Pelotas Research Ethics Committee was obtained for each of the follow-ups. For the latest follow-ups, written consent was obtained from all subjects. In accordance with the guidelines of the local ethics committees, all adolescents whose parents signed an informed consent were included in the study.

\section{RESULTS}

In 2004-2005, a total of 4452 cohort members were interviewed. Including known deaths, the follow-up rate was $87.5 \%$ of live births in 1993 . Follow-up rates were similar for both sexes and across different birth weight categories. There were fewer losses among those with lower and middle family income at birth and among offspring of mothers with 9-11 years of schooling. In spite of these differences, at least $80 \%$ of adolescents in each category were traced.
The proportion of males and females was equally distributed throughout the sample; two-thirds of subjects classified themselves as white (Table 1). Approximately $75 \%$ of mothers had less than 9 years of schooling. SEP between 1993 and 2004 improved for almost $11 \%$ of subjects, and a similar proportion moved in the opposite direction. Only $8 \%$ of subjects remained in the lowest SEP quintile in both periods.

Family and social aspects of QoL are also described in Table 1 . Poor relationship with fathers was three times more

TABLE 1. Descriptive analysis of conditions at birth (sociodemographic variables) and at 11 years of age (family and social aspects of quality of life) among the 1993 Pelotas Birth Cohort Study and the 2004-2005 follow-up study

\begin{tabular}{|c|c|c|}
\hline Variable $^{\mathrm{a}}$ & No. & $\%$ \\
\hline \multicolumn{3}{|l|}{ Skin color } \\
\hline White & 2953 & 66.8 \\
\hline Black/mixed & 1259 & 28.5 \\
\hline Yellow/indigenous & 208 & 4.7 \\
\hline \multicolumn{3}{|l|}{ Sex } \\
\hline Male & 2606 & 49.7 \\
\hline Female & 2642 & 50.3 \\
\hline \multicolumn{3}{|l|}{ Maternal education in $1993^{b}$} \\
\hline $0-4$ years & 1468 & 28.0 \\
\hline $5-8$ & 2424 & 46.2 \\
\hline $9-11$ & 923 & 17.6 \\
\hline$\geq 12$ & 427 & 8.2 \\
\hline \multicolumn{3}{|c|}{ Change in socioeconomic status $(1993-2004)^{c}$} \\
\hline Always poor & 330 & 7.9 \\
\hline Poor-non-poor & 473 & 11.3 \\
\hline Non-poor-poor & 511 & 12.2 \\
\hline Never poor & 2888 & 68.7 \\
\hline \multicolumn{3}{|l|}{ Relationship with father } \\
\hline Excellent-very good & 3092 & 72.3 \\
\hline Good & 665 & 15.5 \\
\hline Bad-very bad & 522 & 12.2 \\
\hline \multicolumn{3}{|l|}{ Relationship with mother } \\
\hline Excellent-very good & 3650 & 84.1 \\
\hline Good & 499 & 11.5 \\
\hline Bad-very bad & 190 & 4.4 \\
\hline \multicolumn{3}{|l|}{$\begin{array}{l}\text { Physically punished by parents } \\
\text { ( } \geq 6 \text { times in the last } 6 \text { months) }\end{array}$} \\
\hline No & 3742 & 86.3 \\
\hline Yes & 593 & 13.7 \\
\hline \multicolumn{3}{|l|}{ Frequent family conflicts } \\
\hline No & 3918 & 93.6 \\
\hline Yes & 268 & 6.4 \\
\hline \multicolumn{3}{|c|}{ Family relationship problems ( $>1$ altercation) } \\
\hline No & 3785 & 94.0 \\
\hline Yes & 241 & 6.0 \\
\hline \multicolumn{3}{|l|}{ Fear of neighborhood } \\
\hline No & 3724 & 84.0 \\
\hline Yes & 709 & 16.0 \\
\hline \multicolumn{3}{|l|}{ Victim of discrimination } \\
\hline No & 3711 & 83.6 \\
\hline Yes & 726 & 16.4 \\
\hline \multicolumn{3}{|l|}{ Academic failure (> once) } \\
\hline No & 3707 & 85.6 \\
\hline Yes & 624 & 14.4 \\
\hline
\end{tabular}


TABLE 2a. Crude and adjusted analysis (prevalence ratios (PR) and confidence interval $(95 \% \mathrm{Cl})$ ) for family aspects of quality of life (bad relationship with parent and frequent family conflicts) at 11 years of age according to sociodemographic variables, Pelotas, Brazil

\begin{tabular}{|c|c|c|c|c|c|c|c|c|c|c|c|c|}
\hline & \multicolumn{4}{|c|}{ Bad relationship with mother } & \multicolumn{4}{|c|}{ Bad relationship with father } & \multicolumn{4}{|c|}{ Frequent family conflicts } \\
\hline & & & $\begin{array}{c}\text { Crude } \\
\text { analysis }\end{array}$ & $\begin{array}{l}\text { Adjusted } \\
\text { analysis }\end{array}$ & & & $\begin{array}{l}\text { Crude } \\
\text { analysis }\end{array}$ & $\begin{array}{l}\text { Adjusted } \\
\text { analysis }\end{array}$ & & & $\begin{array}{c}\text { Crude } \\
\text { analysis }\end{array}$ & $\begin{array}{l}\text { Adjusted } \\
\text { analysis }\end{array}$ \\
\hline & No. & $\%$ & PR $(95 \% \mathrm{Cl})$ & PR $(95 \% \mathrm{Cl})$ & No. & $\%$ & PR $(95 \% \mathrm{Cl})$ & PR $(95 \% \mathrm{Cl})$ & No. & $\%$ & PR (95\%Cl) & PR $(95 \% \mathrm{Cl})$ \\
\hline Skin color & & & $P=0.01^{a}$ & $P=0.06^{a}$ & & & $P<0.001^{a}$ & $P=0.001^{a}$ & & & $P=0.3^{\mathrm{a}}$ & $P=0.4^{a}$ \\
\hline White & 2903 & 3.8 & 1.0 & $1.0^{b, c}$ & 2867 & 10.7 & 1.0 & $1.0^{\mathrm{b}, \mathrm{c}}$ & 2773 & 6.1 & 1.0 & $1.0^{b, c}$ \\
\hline Nonwhite & 1425 & 5.5 & $1.5(1.1-1.9)$ & $1.3(1.0-1.7)$ & 1401 & 15.2 & $1.4(1.2-1.7)$ & $1.3(1.1-1.6)$ & 1402 & 6.9 & $1.1(0.9-1.4)$ & $1.1(0.9-1.4)$ \\
\hline Female & 2213 & 4.2 & $0.9(0.7-1.2)$ & $0.9(0.7-1.2)$ & 2186 & 13.3 & $1.2(1.1-1.4)$ & $1.2(1.0-1.4)$ & 2149 & 5.8 & $0.8(0.7-1.0)$ & $0.8(0.6-1.0)$ \\
\hline $\begin{array}{l}\text { Maternal education } \\
\text { (in 1993) }\end{array}$ & & & $P<0.001^{e}$ & $P<0.001^{\mathrm{e}}$ & & & $P<0.001^{\mathrm{e}}$ & $P<0.001^{e}$ & & & $P=0.006^{\mathrm{a}}$ & $P=0.006^{a}$ \\
\hline $0-4$ & 1184 & 5.4 & $3.5(1.4-8.6)$ & $3.2(1.3-8.0)$ & 1162 & 14.9 & $2.7(1.7-4.3)$ & $2.4(1.5-3.9)$ & 1139 & 7.6 & $1.0(0.7-1.6)$ & $1.1(0.7-1.6)$ \\
\hline $5-8$ & 2079 & 5.1 & $3.3(1.4-8.0)$ & $3.1(1.3-7.6)$ & 2052 & 12.3 & $2.2(1.4-3.5)$ & $2.1(1.3-3.3)$ & 2011 & 6.6 & $0.9(0.6-1.4)$ & $0.9(0.6-1.4)$ \\
\hline $9-11$ & 745 & 1.9 & $1.2(0.4-3.4)$ & $1.2(0.4-3.3)$ & 736 & 10.2 & $1.8(1.1-3.0)$ & $1.8(1.1-2.9)$ & 714 & 3.5 & $0.5(0.3-0.8)$ & $0.5(0.3-0.8)$ \\
\hline Always poor & 319 & 8.5 & $2.9(1.9-4.3)$ & $2.5(1.6-3.9)$ & 307 & 18.9 & $1.9(1.5-2.5)$ & $1.7(1.3-2.3)$ & 308 & 10.4 & $1.9(1.3-2.7)$ & $1.7(1.2-2.5)$ \\
\hline Poor-non-poor & 457 & 5.0 & $1.7(1.1-2.7)$ & $1.5(1.0-2.4)$ & 454 & 11.9 & $1.2(0.9-1.6)$ & $1.1(0.8-1.5)$ & 504 & 7.7 & $1.4(1.0-1.9)$ & $1.3(0.9-1.9)$ \\
\hline Non-poor-poor & 490 & 7.4 & $2.5(1.7-3.6)$ & $2.1(1.4-3.2)$ & 482 & 17.6 & $1.8(1.4-2.2)$ & $1.6(1.3-2.1)$ & 491 & 7.1 & $1.3(0.9-1.8)$ & $1.2(0.8-1.7)$ \\
\hline Never poor & 2835 & 3.0 & 1.0 & $1.0^{c, d}$ & 2807 & 9.9 & 1.0 & $1.0^{\mathrm{c}, \mathrm{d}}$ & 2883 & 5.6 & 1.0 & $1.0^{\mathrm{c}, \mathrm{d}}$ \\
\hline
\end{tabular}

${ }^{a}$ Wald's test for heterogeneity.

${ }^{\mathrm{b}}$ Adjusted for sex.

${ }^{c}$ Adjusted for maternal education in 1993.

${ }^{\mathrm{d}}$ Adjusted for skin color.

e Wald's test for trend.

TABLE $2 \mathrm{~b}$. Crude and adjusted analysis (prevalence ratios (PR) and confidence interval $(95 \% \mathrm{Cl})$ ) for family aspects of quality of life (physical punishment and family relationship problems) at 11 years of age according to sociodemographic variables, Pelotas, Brazil

\begin{tabular}{|c|c|c|c|c|c|c|c|c|}
\hline & \multicolumn{4}{|c|}{$\begin{array}{l}\text { Physically punished by parents } \\
\text { ( } \geq 6 \text { times in the last } 6 \text { months) }\end{array}$} & \multicolumn{4}{|c|}{$\begin{array}{l}\text { Family relationship problems } \\
\qquad(>1 \text { altercation })\end{array}$} \\
\hline & \multirow[b]{2}{*}{ No. } & \multirow[b]{2}{*}{$\%$} & \multirow{2}{*}{$\frac{\text { Crude analysis }}{\text { PR }(95 \% \mathrm{Cl})}$} & \multirow{2}{*}{$\frac{\text { Adjusted analysis }}{\text { PR }(95 \% \mathrm{Cl})}$} & \multirow[b]{2}{*}{ No. } & \multirow[b]{2}{*}{$\%$} & \multirow{2}{*}{$\frac{\text { Crude analysis }}{\text { PR }(95 \% \mathrm{Cl})}$} & \multirow{2}{*}{$\frac{\text { Adjusted analysis }}{\text { PR }(95 \% \mathrm{Cl})}$} \\
\hline & & & & & & & & \\
\hline Skin color & & & $P<0.001^{\mathrm{a}}$ & $P<0.001^{\mathrm{a}}$ & & & $P=0.001^{a}$ & $P=0.02^{\mathrm{a}}$ \\
\hline White & 2892 & 11.8 & 1.0 & $1.0^{\mathrm{b}, \mathrm{c}}$ & 2687 & 5.1 & 1.0 & $1.0^{\mathrm{b}, \mathrm{c}}$ \\
\hline Nonwhite & 1430 & 17.5 & $1.5(1.3-1.7)$ & $1.4(1.2-1.6)$ & 1328 & 7.8 & $1.5(1.2-1.9)$ & $1.4(1.1-1.7)$ \\
\hline Female & 2212 & 11.0 & $0.7(0.6-0.8)$ & $0.7(0.6-0.8)$ & 2071 & 5.5 & $0.8(0.7-1.1)$ & $0.9(0.7-1.2)$ \\
\hline Maternal education & & & & & & & & \\
\hline & & & $P<0.001^{\mathrm{e}}$ & $P<0.001^{\mathrm{e}}$ & & & $P<0.001^{\mathrm{e}}$ & $P<0.001^{\mathrm{e}}$ \\
\hline $0-4$ & 1187 & 17.1 & $2.1(1.4-3.0)$ & $2.0(1.3-2.9)$ & 1086 & 8.0 & $3.5(1.7-7.6)$ & $3.2(1.5-6.9)$ \\
\hline $5-8$ & 2074 & 13.9 & $1.7(1.2-2.4)$ & $1.6(1.1-2.4)$ & 1937 & 6.7 & $3.0(1.4-6.3)$ & $2.8(1.3-5.9)$ \\
\hline $9-11$ & 742 & 9.7 & $1.2(0.8-1.8)$ & $1.2(0.8-1.8)$ & 687 & 2.3 & $1.0(0.4-2.5)$ & $1.0(0.4-2.4)$ \\
\hline$\geq 12$ & 325 & 8.3 & 1.0 & $1.0^{\mathrm{b}, \mathrm{c}}$ & 309 & 2.3 & 1.0 & $1.0^{b, c}$ \\
\hline Non-poor-poor & 508 & 19.1 & $1.6(1.3-2.0)$ & $1.4(1.1-1.7)$ & 448 & 8.3 & $2.0(1.4-2.9)$ & $1.7(1.2-2.5)$ \\
\hline Never poor & 2983 & 11.8 & 1.0 & $1.0^{\mathrm{b}, \mathrm{d}}$ & 2646 & 4.0 & 1.0 & $1.0^{\mathrm{b}, \mathrm{d}}$ \\
\hline
\end{tabular}

a Wald's test for heterogeneity.

${ }^{\mathrm{b}}$ Adjusted for skin color.

${ }^{\mathrm{c}}$ Adjusted for sex.

${ }^{\mathrm{d}}$ Adjusted for maternal education in 1993.

e Wald's test for trend. 
TABLE 3. Crude and adjusted analysis (prevalence ratios (PR) and confidence interval $(95 \% \mathrm{Cl})$ ) for social aspects of quality of life at 11 years of age according to sociodemographic variables, Pelotas, Brazil

\begin{tabular}{|c|c|c|c|c|c|c|c|c|c|c|c|c|}
\hline & \multicolumn{4}{|c|}{ Fear of neighborhood of residence } & \multicolumn{4}{|c|}{ Victim of discrimination } & \multicolumn{4}{|c|}{ Academic failure (> once) } \\
\hline & & & $\begin{array}{c}\text { Crude } \\
\text { analysis }\end{array}$ & $\begin{array}{l}\text { Adjusted } \\
\text { analysis }\end{array}$ & & & $\begin{array}{c}\text { Crude } \\
\text { analysis }\end{array}$ & $\begin{array}{l}\text { Adjusted } \\
\text { analysis }\end{array}$ & & & $\begin{array}{c}\text { Crude } \\
\text { analysis }\end{array}$ & $\begin{array}{l}\text { Adjusted } \\
\text { analysis }\end{array}$ \\
\hline & No. & $\%$ & PR $(95 \% \mathrm{Cl})$ & PR $(95 \% \mathrm{Cl})$ & No. & $\%$ & PR $(95 \% \mathrm{Cl})$ & PR $(95 \% \mathrm{Cl})$ & No. & $\%$ & PR $(95 \% \mathrm{Cl})$ & PR $(95 \% \mathrm{Cl})$ \\
\hline Skin color & & & $P=0.006^{a}$ & $P=0.008^{\mathrm{a}}$ & & & $P<0.001^{a}$ & $P<0.001^{a}$ & & & $P<0.001^{a}$ & $P<0.001^{a}$ \\
\hline White & 2951 & 15.0 & 1.0 & $1.0^{\mathrm{b}, \mathrm{c}}$ & 2952 & 14.6 & 1.0 & $1.0^{\mathrm{b}, \mathrm{c}}$ & 2883 & 10.9 & 1.0 & $1.0^{\mathrm{b}, \mathrm{c}}$ \\
\hline Nonwhite & 1467 & 18.2 & $1.2(1.1-1.4)$ & $1.2(1.1-1.4)$ & 1467 & 19.8 & $1.4(1.2-1.6)$ & $1.3(1.1-1.5)$ & 1425 & 21.1 & $1.9(1.7-2.2)$ & $1.6(1.4-1.8)$ \\
\hline Sex & & & $P<0.001^{a}$ & $P<0.001^{a}$ & & & $P=0.006^{a}$ & $P=0.01^{\mathrm{a}}$ & & & $P<0.001^{a}$ & $P=0.01^{a}$ \\
\hline Male & 2177 & 14.0 & 1.0 & $1.0^{\mathrm{b}, \mathrm{d}}$ & 2093 & 14.8 & 1.0 & $1.0^{\mathrm{b}, \mathrm{d}}$ & 2125 & 18.4 & 1.0 & $1.0^{\mathrm{b}, \mathrm{d}}$ \\
\hline Female & 2256 & 18.0 & $1.3(1.1-1.5)$ & $1.3(1.1-1.5)$ & 2186 & 17.9 & $1.2(1.1-1.4)$ & $1.2(1.1-1.4)$ & 2206 & 10.6 & $0.6(0.5-0.7)$ & $0.6(0.5-0.7)$ \\
\hline \multicolumn{13}{|l|}{ Maternal education } \\
\hline (in 1993) & & & $P=0.6^{\mathrm{e}}$ & $P=1.0^{\mathrm{e}}$ & & & $P<0.001^{e}$ & $P<0.001^{e}$ & & & $P<0.001^{\mathrm{e}}$ & $P<0.001^{\mathrm{e}}$ \\
\hline $0-4$ & 1225 & 16.0 & $1.0(0.7-1.3)$ & $0.9(0.7-1.2)$ & 1227 & 20.1 & $1.7(1.2-2.3)$ & $1.5(1.1-2.1)$ & 1196 & 27.7 & $22.3(8.4-59.4)$ & $19.5(7.3-51.9)$ \\
\hline $5-8$ & 2121 & 16.6 & $1.0(0.8-1.3)$ & $0.9(0.7-1.2)$ & 2120 & 15.9 & $1.3(1.0-1.8)$ & $1.3(0.9-1.7)$ & 2026 & 12.6 & $10.2(3.8-27.1)$ & $9.2(3.4-24.5)$ \\
\hline $9-11$ & 752 & 14.0 & $0.8(0.6-1.1)$ & $0.8(0.6-1.1)$ & 755 & 13.6 & $1.2(0.8-1.6)$ & $1.1(0.8-1.5)$ & 738 & 3.7 & $3.0(1.0-8.4)$ & $2.7(1.0-7.8)$ \\
\hline$\geq 12$ & 328 & 16.8 & 1.0 & $1.0^{\mathrm{b}, \mathrm{c}}$ & 328 & 11.9 & 1.0 & $1.0^{\mathrm{b}, \mathrm{c}}$ & 323 & 1.2 & 1.0 & $1.0^{\mathrm{b}, \mathrm{c}}$ \\
\hline \multicolumn{13}{|l|}{$\begin{array}{l}\text { Change in } \\
\text { socioeconomic }\end{array}$} \\
\hline status (1993-2004) & & & $P=0.6^{\mathrm{a}}$ & $P=0.8^{\mathrm{a}}$ & & & $P<0.001^{a}$ & $P<0.001^{a}$ & & & $P<0.001^{a}$ & $P<0.001^{\mathrm{a}}$ \\
\hline Always poor & 329 & 18.2 & $1.2(0.9-1.5)$ & $1.1(0.9-1.5)$ & 329 & 23.4 & $1.7(1.4-2.1)$ & $1.6(1.3-2.0)$ & 319 & 35.7 & $4.3(3.6-5.3)$ & $2.5(2.0-3.1)$ \\
\hline Poor-non-poor & 471 & 15.7 & $1.0(0.8-1.3)$ & $1.0(0.8-1.3)$ & 473 & 18.0 & $1.3(1.1-1.6)$ & $1.3(1.0-1.6)$ & 464 & 20.0 & $2.4(3.0-3.0)$ & $1.7(1.3-2.1)$ \\
\hline Non-poor-poor & 509 & 16.3 & $1.1(0.9-1.3)$ & $1.0(0.8-1.3)$ & 509 & 22.2 & $1.6(1.4-2.0)$ & $1.5(1.3-1.9)$ & 494 & 22.9 & $2.8(2.3-3.4)$ & $1.7(1.4-2.1)$ \\
\hline Never poor & 2876 & 15.4 & 1.0 & $1.0^{\mathrm{b}, \mathrm{d}}$ & 2878 & 13.6 & 1.0 & $1.0^{\mathrm{b}, \mathrm{d}}$ & 2839 & 8.2 & 1.0 & $1.0^{\mathrm{b}, \mathrm{d}}$ \\
\hline
\end{tabular}

a Wald's test for heterogeneity.

${ }^{\mathrm{b}}$ Adjusted for skin color.

${ }^{c}$ Adjusted for sex.

${ }^{\mathrm{d}}$ Adjusted for maternal education in 1993.

e Wald's test for trend.

frequent than with mothers. Physical punishment by parents ( $\geq 6$ times in the last 6 months) was twice as prevalent as family conflicts. Family relationship problems ( $>1$ altercation) affected $6 \%$ of the cohort members. Prevalence of academic failure, fear of neighborhood, and discrimination were close to $15 \%$ for each variable.

Tables $2 \mathrm{a}$ and $2 \mathrm{~b}$ show the results of crude and adjusted analyses for family aspects of QoL: poor relationship with mothers, poor relationship with fathers, family conflicts, frequent physical punishment by parents, and family relationship problems. Skin color was associated with almost all the outcomes in crude and adjusted analyses (30\%-40\% higher risk among non-whites compared to whites), with the exception of family conflicts. Conversely, sex was only associated with physical punishment by parents in crude and adjusted analyses, which was 30\% less common among girls. Maternal education was inversely associated with poor relationship with fathers and mothers, physical punish- ment, and family relationship problems. The association with family conflicts was U-shaped and the intermediate level of maternal education (9-11 years) showed a protective effect. Current poverty (always poor and non-poor/poor) was adversely associated with all family aspects of QoL, with the exception of family conflicts, which were more frequent only among those always poor.

Crude and adjusted analyses for social aspects of QoL-fear of the neighborhood of residence, discrimination, and academic failure-are shown in Table 3. Fear of the neighborhood and discrimination were $20 \%-30 \%$ more frequent among women and nonwhites when compared to their respective reference groups. Nonwhite adolescents also showed higher risk of academic failure and, conversely, being female provided a protective effect. Maternal education was inversely associated with discrimination in crude and adjusted analyses, but not with fear of the neighborhood. Academic failure was 20 times more frequent among adolescents with lower maternal education at birth (0-4 years) than those with higher education, even after controlling for potential confounders. Likewise, SEP change was not associated with fear of neighborhood, but was associated with discrimination, which was more frequent among those currently poor (always poor and non-poor-poor). Academic failure was also 2.5 times more frequent among subjects who were always poor when compared to those who were never poor, with intermediate risk for the other two categories.

Additional analyses were carried out to explore possible pathways between skin color and the outcomes. After adjustment for SEP change, only the associations with maternal relationship and family relationship problems were reduced, these being no longer statistically significant.

Effect modification by sex or skin color was also analyzed, but no evidence of interactions was found ( $P$-value for interaction $>0.2$ in all the cases).

A summary of findings is included in Table 4. 
TABLE 4. Higher risk groups in the association between sociodemographic variables and quality of life among adolescents (summary of adjusted analyses), 1993 Pelotas Birth Cohort Studies and 2004 followup, Pelotas, Brazil

\begin{tabular}{|c|c|c|c|c|}
\hline & $\begin{array}{l}\text { Skin color } \\
(2004-2005)\end{array}$ & $\begin{array}{c}\text { Sex } \\
(1993)\end{array}$ & $\begin{array}{l}\text { Maternal education } \\
\text { at birth (1993) }\end{array}$ & $\begin{array}{l}\text { Change in socioeconomic } \\
\text { position (1993-2004) }\end{array}$ \\
\hline Poor relationship with mother & Nonwhite & $-{ }^{a}$ & Low & Always poor and non-poor/poor \\
\hline Poor relationship with father & Nonwhite & - & Low & Always poor and non-poor/poor \\
\hline Frequent family conflicts & - & - & Low and high & Always poor \\
\hline $\begin{array}{l}\text { Physical punishment by parents } \\
\text { ( } \geq 6 \text { in the last } 6 \text { months) }\end{array}$ & Nonwhite & Male & Low & Always poor and non-poor/poor \\
\hline Family relationship problems & Nonwhite & - & Low & Always poor and non-poor/poor \\
\hline Fear of neighborhood & Nonwhite & Female & - & - \\
\hline Discrimination & Nonwhite & Female & Low & Always poor and non-poor/poor \\
\hline Academic failure & Nonwhite & Male & Low & Always poor \\
\hline
\end{tabular}

a Not associated.

\section{DISCUSSION}

This study sought to examine the effects of sex, skin color, maternal education at birth, and SEP change on some family and social aspects of QoL among adolescents (11-12 years of age) in the 1993 Pelotas Birth Cohort. In accordance with the initial hypothesis, the results (Table 4) showed that: (a) except for family conflicts, all the family and social aspects of QoL were worse among nonwhites adolescents; (b) among boys, physical punishment by parents and academic failure were more frequent, whereas among girls discrimination and fear of neighborhood were more prevalent; (c) individuals with lower maternal education at birth and who were always poor (SEP) had most of the family and social aspects of QoL affected, except for fear of neighborhood; and (d) the strongest association was found between lower maternal education and academic failure.

The association between self-reported skin color and the family and social aspects of QoL reflects a range of social conditions that are unfavorable to nonwhites. In Brazil, skin color has been more widely used in the epidemiological context to measure social differences in health outcomes and treatment, but is not an accurate predictor of ancestry in this population (23). The results of the present study concur with those of other studies that show that in adolescents, skin color/ethnicity is related to well being and aspects of QoL (7, 24-27). According to Brazilian surveys (1993-2007), inequities related to skin color have been attributed to black/brown individuals having lower income, lower education, worse household conditions (healthiness and security), and being more susceptible to socioeconomic and racial discrimination than whites (28). Compared to other regional cities in the state, Pelotas has a higher proportion of black/brown individuals $(16.1 \%)$, and this could potentially attenuate social inequities related to skin color (29). However, this study's findings showed consistently that skin color affected almost all aspects of QoL, even in early adolescence, and that these effects were not explained by SEP.

Early poverty and lower maternal education were related to academic failure, principally affecting males. Concurring with this study's results, other studies (30-33) have found the same relationships: boys have worse academic performance and are more predisposed to poor academic habits than girls. The mechanisms related to this finding are complex and not well understood, and include individual, familiar, educational, and social characteristics. In Brazil, socioeconomic and cultural factors among poor families are such that boys are taught to develop responsibility for the family's financial situation at an early age (34). A study carried out in Pelotas in 1998 showed that children and adolescent boys contribute, on average, up to $18 \%$ of the family income. Moreover, the higher the contribution, the higher the school dropout rate for these adolescents (35). The present results raise questions regarding the qual- ity and structure of the educational system in Brazil, and the importance of remaining in school for the poorest.

Physical punishment was more frequent among males, black/brown individuals with lower maternal education, and among those always poor. Some Brazilian studies also showed that poverty, parental stress, and other family characteristics-such as domestic violence-are related to physical punishment by parents, and this practice can affect mental health and behavioral outcomes in children $(36,37)$. Additionally, physical punishment may represent either an exposure or an outcome for other variables in adolescence, such as academic failure and/or attempts at independence from parental control (both more frequent among males) (38); however, this specific pathway was not examined, and further study may be necessary.

Fear of neighborhood was more frequent among females, probably because they are considered to be more susceptible to urban violence, shown by prior study of the same cohort (39). Leisure time among girls is more tightly controlled by the family, thereby reducing the amount of time spent engaging in social interactions outside the home environment. This leads to differences in how males and females perceive their social surroundings, and according to the results of this present study, is not mediated by SEP.

Additionally, fear of neighborhood affected all socioeconomic groups in a simi- 
lar way, probably because this outcome is more related to the spatial distribution of specific dangerous places inside the neighborhood than to the size or socioeconomic characteristics of the locality (40).

Discrimination was also more frequent among females. In adolescence, various discriminatory practices, such as teasing, bullying, and assigning nicknames (related to physical appearance) are common at school $(38,41,42)$. In this study's cohort, most forms of discriminationskin color, poverty, and physical appearance-were more frequent among females (data not shown). However, male Brazilian adults are more affected by discriminatory practices related to skin color and SEP $(33,38)$. There are no other population based studies in Brazil evaluating discrimination in early adolescence, and further studies evaluating the interactions between gender, stage of life, and discrimination are necessary.

Maternal education is an important social marker for health outcomes (4345 ), and in this study it was related to family and social aspects of QoL, particularly regarding academic failure. This variable reflects a mother's knowledge, practices, and life aspirations, which can be directly or indirectly transmitted to offspring. For example, maternal education has been related to quality of care of children, which in turn can affect physical and mental well-being in offspring. Maternal education also represents a more stable indicator of SEP than does family income. However, due to the longitudinal design of this study, we were able to evaluate socioeconomic trajectories from birth to early adolescence. Con- sistent with the results for maternal education, the cumulative effect of poverty increased the risk of alteration in most of the family and social aspects of QoL.

The prospective design of this study reduces the possibility of reversal causality in the findings. However, there are several possible limitations in the present study. Losses at follow-up are an important limitation of prospective studies, but only $12.5 \%$ of the original cohort was missed at 11 years of age. The application of a confidential questionnaire resulted in a high response rate for family relationship questions ( $~ 95 \%$ for all of them), reducing the probability of information bias. Another limitation is that the study did not employ a specific questionnaire to evaluate QoL in adolescence. Nevertheless, all the results consistently pointed out the relevance of sociodemographic conditions on the outcomes. To confirm the results, the 1993 Pelotas Birth Cohort Study is planning to evaluate QoL with a standardized questionnaire administered at 18 years of age. In addition, QoL can be affected across the life-course and may vary for different exposures, such as age and sociopolitical context (46). Therefore, the present findings may not be extrapolated to other population groups and/or other ages, even for the same city. However, inequities associated with gender, skin color, and SEP have been related to different health outcomes at different ages and in different populations (20).

In conclusion, adolescents belonging to lower socioeconomic groups showed worse QoL than the wealthiest groups. The underlying mechanisms are not well known, but probably involve the effects of lower parental education on physical and psychological health of offspring. This study also showed than lower SEP across the life-course has a cumulative effect on QoL, principally for academic failure and family relationships. Skin color was related to family and social aspects of QoL, independent of SEP. In spite of this, other social and cultural characteristics may be involved and new studies are necessary. Gender was also important for QoL in adolescence: in girls, social aspects were particularly affected, while in boys academic failure and physical punishment by parents were affected.

These results suggest that policies should be directed principally to improving access to high quality education, especially in the lower SEP groups, for both parents and children. This would help to minimize inequities at birth, across the life-course, and in the next generation.

Acknowledgements. The authors wish to thank Fernando Barros, Cesar Victora, Maria de Fátima Vieira, Marilda Neutzling, Pedro R. C. Hallal, and Neiva Valle for their important collaboration in the different stages and levels of the Pelotas 1993 Birth Cohort Study.

The present study was supported by the Wellcome Trust (United Kingdom). The initial stages of the cohort were supported by the European Union, the Programa Nacional para Centros de Excelência (PRONEX) of the Conselho Nacional de Desenvolvimento Científico e Tecnológico (CNPq), and by the Ministry of Health of Brazil.

\section{REFERENCES}

1. World Health Organization Quality of Life Assessment Group. WHOQOL: position paper from the World Health Organization. Soc Sci Med. 1995;41:1403-10.

2. Haas BK. A multidisciplinary concept analysis of quality of life. West J Nurs Res. 1999; 21(6):728-42.

3. Dijkers M. "What's in a name?" The indiscriminate use of the "quality of life" label, and the need to bring about clarity in conceptualizations. Int J Nurs Stud. 2007;44: 153-5.

4. Moonsa P, Budtsb W, De Geesta S. Critique on the conceptualisation of quality of life: A review and evaluation of different concep- tual approaches. Int J Nurs Stud. 2006;43: 891-901.

5. Huebner E, Valois R, Suldo S, Smith S, McKnight C, Seligson J, et al. Perceived quality of life: a neglected component of adolescent health assessment and intervention. J Adolesc Health. 2004;34(4):270-8.

6. Smith KW, Avis NE, Assmann SF. Distinguishing between quality of life and health status in quality of life research: a meta-analysis. Qual Life Res. 1999;8:447-59.

7. von Rueden U. SE determinants of health related QoL in childhood and adolescenceeuropean study. J Epidemiol Community Health. 2006;60:130-5.
8. Lima MG, Barros MB, César CL, Goldbaum M, Carandina L, Ciconelli RM, et al. Impact of chronic disease on quality of life among the elderly in the state of São Paulo, Brazil: a population-based study. Rev Panam Salud Publica. 2009;25(4):314-21.

9. Barker DJ. The fetal and infant origins of adult disease. BMJ. 1990;301(6761):1111.

10. Joseph K, Kramer MS. Review of the evidence on fetal and early childhood antecedents of adult chronic disease. Epidemiol Rev. 1996;18: 158-74.

11. Victora C, Adair L, Fall C, Hallal PC, Martorell R, Richter L, et al. Maternal and child undernutrition: consequences for adult 
health and human capital. Lancet. 2008;371: 340-57.

12. Ventegodt $\mathrm{S}$, Flensborg-Madsen $\mathrm{T}$, Andersen NJ, Merrick J. Factors during pregnancy, delivery and birth affecting global quality of life of the adult child at long-term follow-up. Results from the prospective Copenhagen Perinatal Birth Cohort 1959-61. Scientific World Journal. 2005;1(5):933-41.

13. Abbott R, Croudace T, Ploubidis G, Kuh D, Richards M, Huppert FA. The relationship between early personality and midlife psychological well-being: evidence from a UK birth cohort study. Soc Psychiatry Psychiatr Epidemiol. 2008;43(9):679-87.

14. Golding J, Pembrey M, Jones R. Avon longitudinal study of parents and children. Paediatr Perinat Epidemiol. 2001;15(1):74-87.

15. European Commission. Report on the state of young people's health in the European Union: a commission services working paper. Available from: http://europa.eu.int/comm/ health/ph_information/reporting/ke01_en. pdf. Accessed 14 March 2002.

16. Strully KW, Conley D. Reconsidering risk: adapting public policies to intergenerational determinants and biosocial interactions in health-related needs. J Health Polit Policy Law. 2004;9(6):1073-108.

17. Janse AJ, Gemke RJ, Uiterwaal CS, van der Tweel I, Kimpen I, Sinnema G. 'Quality of life: patients and doctors don't always agree: a metaanalysis'. J Clin Epidemiol. 2004:57(7):653-61.

18. Victora CG, Hallal PC, Araujo CL, Menezes AMB, Wells J, Barros FC. Cohort profile: The 1993 Pelotas (Brazil) birth cohort study. Int J Epidemiol. 2007;37(4):704-9.

19. Harpham T, Huttly S, Wilson I, Wet T. Linking public issues with private troubles: panel studies in developing countries. J Int Dev. 2003;15:353-63.

20. Victora CG, Araújo CL, Menezes AM, Hallal PC, Vieira MF, Neutzling MB et al. Methodological aspects of the 1993 Pelotas (Brazil) birth cohort study. Rev Saude Publ. 2006; 40(1):39-46.

21. Instituto Brasileiro de Geografia e Estatística. Indicadores sociais mínimos. Conceitos. Available from: http://www.ibge.gov.br/ home/estatistica/populacao/condicaodev $\mathrm{ida} /$ indicadoresminimos/conceitos.shtm. Accessed 22 April 2009.

22. Batty GB, Horta BL, Smith GD, Barros FC, Victora CV. Early life diarrhoea and later blood pressure in a developing country: the 1982 Pelotas (Brazil) birth cohort study. J Epidemiol Community Health. 2009;63(2):163-5.
23. Kaplan JB, Bennett T. Use of race and ethnicity in biomedical publication. JAMA. 2003; 289:2709-16.

24. Carvalho M. Who is black, who is white: school performance and the racial classification of school children. Rev Bras Educ. 2005;28:77-95.

25. Alves $P$, Franco $C$, Ortigão MIR. Origem social e risco de repetência: interação raçacapital econômico. Cad Pesqui. 2007;37(130): 161-80.

26. Smetana JG, Campione-Barr N, Metzger A. Adolescent development in interpersonal and societal contexts. Annu Rev Psychol. 2006;57: 255-84.

27. Bradley RH, Corwyn RF. Socioeconomic status and child development. Annu Rev Psychol. 2002;53:371-9.

28. Secretaria Especial de Políticas para as Mulheres Instituto de Pesquisa Econômica Aplicada; Fundo de Desenvolvimento das Nações Unidas para a Mulher. Retrato das desigualdades de gênero e raça. Available from: http://www.ipea.gov.br/sites/000/2/desta que/Pesquisa_Retrato_das_Desigualdades. pdf. Accessed 12 May 2009.

29. Instituto Brasileiro de Geografia e Estatística. Censo brasileiro 2000. Rio de Janeiro; 2001. Available from: http://www.ibge.gov.br/ home/estatistica/populacao/censo2000/ default.shtm. Accessed 12 April 2009.

30. Kutnick P. Girls, boys and school achievement: Critical comments on who achieves in schools and under what economic and social conditions achievement takes place- $\mathrm{a}$ Caribbean perspective. Int J Educ Dev. 2000;20(1): 65-84.

31. Damiani MF. Pedagogic discourse and academic failure in Southern Brazil. In: Harry Daniels; Philip Garner (Eds). World Yearbook 1999: Issue on inclusive education. 1 ed. London: Kogan Page, 1999:169-77.

32. Carvalho MP. Mau aluno, boa aluna? Como as professoras avaliam meninos e meninas. Estud Fem. 2001;9(2):554-74.

33. Carvalho MP. Quem são os meninos que fracassam na escola? Cad Pesqui. 2004;34(121): $11-40$.

34. Gonçalves H, Gigante D. Trabalho, escolaridade e saúde reprodutiva: um estudo etnoepidemiológico com jovens mulheres pertencentes a uma coorte de nascimento. Cad Saude Publica. 2006;22(7):1459-69.

35. Facchini LA, Fassa AG, Dall'Agnol M, Maia MFS. Trabalho infantil em Pelotas: perfil ocupacional e contribuição à economia. Cienc Saude Coletiva. 2003;8(4):953-61.
36. Bordin IS, Paula CS, Nascimento R, Duarte CS. Severe physical punishment and mental health problems in an economically disadvantaged population of children and adolescents. Rev Bras Psiquiatr. 2006;28(4):290-6.

37. Bauman L, Friedman S. Corporal punishment. Pediatr Clin North Am. 1998;45(2): 403-14.

38. Turner HA, Finkelhor D. Corporal punishment as a stressor among young. J Marriage Fam. 1996;58(1):155-66.

39. Gonçalves H, Hallal PC, Amorim TC, Araujo $\mathrm{CP}$, Menezes AMB. Fatores Socioculturais e nível de atividade física no início da adolescência. Rev Panam Salud Publica. 2007;22 (4):246-53.

40. Drukker M, Kaplan C, Feron F, Van Os J. Children's health-related quality of life, neighbourhood socio-economic deprivation and social capital. A contextual analysis. Soc Sci Med. 2003;57:825-41.

41. Nansel TR, Overpeck M, Pilla RS, June Ruan W, Simons-Morton B, Scheidtet P. Bullying behaviors among US youth: prevalence and association with psychosocial adjustment. JAMA. 2001;285:2094-100.

42. Ravens-Sieberer U, Kökönyei G, Thomas C. School and Health. In: Currie C, Roberts C, Morgan A, et al, eds. Young people's health in context. Health Behavior in School-Aged Children (HBSC) Study: International report from the 2001/2002 survey. Health Policy for Children and Adolescents. World Health Organization: Geneva; 2004. Pp. 84-95.

43. Haidar FH, Oliveira UF, Nascimento LF. Escolaridade materna: correlação com os indicadores obstétricos. Cad Saude Publica. 2001;17(4):1025-9.

44. Monteiro CA, Szarfarc SC, Mondini L. Tendência secular da anemia na infância na cidade de São Paulo (1984-1996). Rev Saude Publica. 2000;34(6):62-72.

45. Victora CG, Huttly SR, Barros FC, Lombardi $C$, Vaughan JP. Maternal education in relation to early and late child health outcomes: findings from a Brazilian cohort study. Soc Sci Med. 1992:34:899-905.

46. Zulling KJ, Valois RF, Huebner ES, Drane JW. Adolescent health-related quality of life and perceived satisfaction with life. Qual Life Res. 2005;14:1573-84

Manuscript received on 11 January 2010. Revised version accepted for publication on 21 June 2010. 
RESUMEN Objetivo. Evaluar la correlación que existe entre ciertos aspectos autonotificados de la calidad de vida en la adolescencia temprana y el género, el color de la piel, la esco-

La repercusión de las condiciones sociodemográficas sobre la calidad de vida de los adolescentes en una cohorte de nacimiento en el Brasil: un estudio longitudinal

Palabras clave laridad materna en el momento del nacimiento y los cambios de situación socioeconómica que ocurren entre el nacimiento y los 11 años.

Métodos. Se llevó a cabo un estudio longitudinal de una cohorte de nacimiento compuesta por 5249 personas nacidas en 1993 en Pelotas (Brasil) a las cuales se les realizó un seguimiento periódico desde el nacimiento hasta los 11 años. Las variables socioeconómicas se recogieron al momento del nacimiento en 1993 y nuevamente en el 2004. Se analizaron las siguientes ocho variables: la relación con la madre, la relación con el padre, los conflictos familiares, el castigo físico infligido por los padres, los problemas de las relaciones familiares, la discriminación, el fracaso académico y el temor al vecindario de residencia. Se realizaron ajustes mediante el uso de un modelo jerárquico. Resultados. El color de la piel se relacionó con todas las variables (aún más en las personas que no eran blancas que en las blancas), con la excepción de los conflictos familiares. El castigo físico y el fracaso académico fueron más frecuentes en los hombres. La discriminación y el temor al vecindario fueron más prevalentes en las mujeres. La escolaridad materna en el momento del nacimiento presentó una relación inversa, especialmente con respecto a la pérdida o la repetición de un año escolar $(19,5$ veces más frecuente en el grupo con escolaridad materna más baja que en el grupo con la mayor escolaridad). Se encontró un perfil similar con los cambios de situación socioeconómica: una calidad de vida inferior en el grupo que siempre fue pobre (al nacimiento y a los 11 años de edad), en comparación con la del grupo que nunca lo fue. El temor al vecindario no se relacionó con la escolaridad materna ni con la variación de la situación socioeconómica.

Conclusiones. El sexo, el color de la piel, la escolaridad de la madre y los cambios de situación socioeconómica se relacionaron con varios aspectos de la calidad de vida que se evaluaron. Es importante considerar estos resultados cuando se formulen las políticas que tienen por objeto reducir al mínimo la falta de equidad al nacimiento, a lo largo de la vida y en las generaciones futuras.

Calidad de vida; estudios de cohortes; estudios longitudinales; adolescente; factores socioeconómicos; pobreza; Brasil. 